\title{
Efektivitas platform guru virtual sebagai platform pembelajaran daring di masa pandemi covid-19
}

\section{Dewi Ratnaningsih}

Universitas Muhammadiyah Kotabumi, Lampung, Indonesia

Correpondence: dewi.ratnaningsih@umko.ac.id

\begin{abstract}
Coronavirus or Covid-19 is viruses group of the Orthocoronavirinae member of Coronaviridae family and the order Nidovirales. This virus can cause disease not only human, but also birds and mammals. The extraordinary events caused by the corona virus become a new problem in various fields of life, including in the field of education. Every educator is required to be able to innovate, so that the learning process and physical limitations can both continue. Therefore, not long after the physical restriction instructions were applied, the online learning model or commonly referred to as e-learning began to be socialized. The purpose of writing this article is to see the effectiveness of the Guru Virtual platform as an daring learning medium. To conduct this research, researcher uses descriptive qualitative method. Qualitative descriptive method is a method that analyzes research in the form of descriptions not in the form of numbers or coefficients about the relationship between variables. The data gathered from the research is in the form of words or pictures not numbers. The data was collected by designing learning scenarios, recording, and interviewing. In addition, the calculation of student learning outcomes is also carried out to see learning outcomes using the Guru Virtual. Based on the results of interviews with students, Guru Virtual is an effective platform to be used as an daring learning platform. Based on the calculation of student learning outcomes, it was obtained an average value of 74.9 with a good category.
\end{abstract}

Keywords: Covid-19; Guru Virtual Platform; Online Learning

\section{Pendahuluan}

Wuhan, Provinsi Hubei, Tiongkok, merupakan lokasi awal ditemukannya virus Corona, dugaan munculnya virus Corona secara spesifik terletak disebuah pasar yang menjajakan berbagai jenis hewan mati dan hidup (Windhiyana, 2020). Hal 
ini juga dikemukakan oleh Adhikari, "COVID-19 has been identified as the cause of an outbreak of infectious respiratory disease in Wuhan, People's Republic of China" (Adhikari et al., 2020). Sejak kemunculan virus ini pada Desember 2019, para peneliti mulai melakukan analisis karakteristik korban yang terinfeksi (Fauci et al., 2020). Covid-19 adalah salah satu virus yang memiliki kemampuan penyebaran yang sangat cepat dan begitu masif. Meluasnya penyebaran Covid-19 telah terjadi di banyak negara, termasuk Indonesia. "Pada tanggal 30 Januari 2020, WHO menetapkan COVID-19 sebagai Public Health Emergency of International Concern (PHEIC)/ Kedaruratan Kesehatan Masyarakat Yang Meresahkan Dunia (KKMMD). Pada tanggal 12 Februari 2020, WHO resmi menetapkan penyakit coronavirus pada manusia ini dengan sebutan Coronavirus Disease (COVID-19). Pada tanggal 2 Maret 2020 Indonesia telah melaporkan 2 kasus konfirmasi COVID-19. Pada tanggal 11 Maret 2020, WHO sudah menetapkan COVID-19 sebagai pandemic" (Kemenkes RI, 2020).

Sebagai respon dari meluasnya penyebaran virus ini, "WHO menyatakan dunia masuk ke dalam darurat global sejak Januari 2020" (Sebayang, 2020). Tidak lama dari penetapan tersebut, setiap negara diminta untuk melakukan pembatasan fisik (physical distancing) guna memutus mata rantai penyebaran Covid-19. Hal tersebut tertuang dalam instruksi presiden tentang penanganan virus Corona (Instruksi Presiden Republik Indonesia Nomor 4 Tahun 2020 Tentang Refocussing Kegiatan,Realokasi Anggaran, Serta Pengadaan Barang Dan Jasa Dalam Rangka Percepatan Penanganan Corona Virus Disease 2019 (Covid-19, n.d.). Menurut Center for Disease (CDC) dalam (Windhiyana, 2020) "Social Distancing yaitu menjauhi perkumpulan, menghindari pertemuan massal, dan menjaga jarak antar manusia." Ketika mulai disosialisasikan oleh pemerintah di segala lini, pembatasan fisik tersebut juga pada akhirnya diterapkan pada bidang pendidikan. Proses pembelajaran yang semula dilakukan secara tatap muka harus dilakukan secara tatap layar.

Pembatasan fisik di sekolah dan perguruan tinggi tentunya sangatlah mengejutkan, mengingat kejadian ini tidak pernah terpikirkan akan terjadi juga di Indonesia. Setiap perguruan tinggi dituntut untuk mampu berinovasi agar proses pembelajaran dan pembatasan fisik dapat sama-sama terus berjalan. Oleh karna itu, tidak lama dari instruksi pembatasan fisik tersebut diterapkan, model pembelajaran daring atau yang biasa disebut sebagai e-learning mulai disosialisasikan. "Pembelajaran elektronik atau e-learning telah dimulai pada tahun 1970-an" (Chandrawati, 2010). Walapun pembelajaran elektronik telah hadir cukup lama, namun pembelajar dan pengajar masih jarang menggunakan. Pemberian materi melalui media secara dalam jaringan harus menghadirkan efek yang menarik dengan menghadirkan kombinasi antara tulisan, gambar, garfik, gerak aniamsi, suara dan video (Aji, 2019).

E-learning atau pembelajaran elektronik merupakan sebuah perangkatan teknologi yang digunakan untuk memudahkan akses pembelajar untuk belajar 
dimana dan kapan saja (Dahiya et al., 2012). Melalui e-learning, proses pembelajaran akan berjalan secara asynchronous. E-learning sebagai kegiatan belajar "asynchronous" dapat dilakukan dengan bantuan perangkat komputer (Rusman., Kurniawan, D dan Riyana, 2011). Selain itu Seok mengungkapkan bahwa e-learning merupakan pembelajaran abad-21. Pembelajaran pada abad ini, diartikan sebagai pembelajaran yang telah memasuki era disrupsi. Meilasari mengemukakan "Pembelajaran era distrupsi setidaknya harus memiliki 3 ciri: 1) ditopang internet, kecerdasan buatan, dan maha data, (2) berlangsung tak terduga dan taksa, dan (3) berlangsung cepat dan tak kasat mata" (Meilasari, 2020).

"E-learning is a new form of pedagogy for learning in the 21st century. $e$ Teacher are e-learning instructional designer, facilitator of interaction, and subject matter expert" (Seok, 2008). E-learning diartikan sebagai pembelajaran yang dilakukan melalui jaringan, Hranstinski mengungkapkan "E-learning, here defined as learning and teaching daring through network technologies, is arguably one of the most powerful responses to the growing need for education" (Hrastinski, 2008).

Sederhana, personal, dan cepat merupakan tiga komponen yang wajib dipenuhi dalam merancang e-learning yang menarik dan diminati (Purbo, 2002). Sederhana diartikan sebagai suatu bentuk e-learning yang langsung mengarah pada pemberian materi, sementara personal dan cepat diartikan sebagai proses pembelajaran yang langsung mengarah pada peserta didik dan dapat dilakukan dimana saja. Perangkat elektronik dalam e-learning adalah perangkat elektronik yang ada kaitannya dengan perangkat elektronik dan multimedia (Sanaky, 2013). Hal ini relevan dengan pernyataan bahwa "elearning atau pembelajaran elektronik meliputi berbagai aplikasi dan proses seperti computer-based learning, webbased learning, virtual classroom, virtual Schoology, virtual Zoom, dan aplikasi lainnya" (Dakwah, S. F., Uin, K., \& Fatah, 20 C.E.)

E-learning jauh lebih kompleks dari m-learning. Dalam penerapannya, $m$ learning dapat menjadi bagian atau bahkan sub-bagian dari e-learning. Dalam hal ini, pemanfaatan m-learning dalam pembelajaran lebih berorientasi pada penyampaian materi/bahan ajar secara menarik yang memadukan beragam media sehingga pemberian informasi dapat lebih mudah diterima peserta didik (Hernawati, 2011). Melalui implementasi pembelajaran berbasis m-learning dan e-learning, kualitas penyelenggaraan pembelajaran atau pendidikan di Indonesia dapat meningkat tiap tahunnya (Ratnaningsih, 2020). Pernyataan tersebut juga telah dikemukakan oleh Rani Jayanti yang mengungkapkan bahwa inovasi bahan ajar juga dilakukan guna meningkatkan kualitas pembelajaran (Jayanti \& Rosita, 2019). Seiring dengan perkembangan teknologi, teknologi $e$ learning kini berkembang menjadi multiplatform e-learning technology (MLT). Penerapan e-learning kini dapat menjadi lebih portable, tidak terbatas hanya 
dengan menggunakan komputer, sehingga proses pembelajaran melalui $e$ learning dapat dilakukan kapan dan dimana saja (Ichwan, 2015). Efektifnya pelaksanaan e-learning sangat relevan dilakukan pada masa Pandemi seperti saat ini. Sampai saat ini, bentuk model pembelajaran daring yang diterapkan oleh perguruan tinggi sangat bervariasi. Mulai dari video konferensi, e-learning, buku digital, dan sebagainya. Salah satu platform pembelajaran yang dapat digunakan adalah Guru Virtual.

Guru Virtual merupakan platform pembelajaran yang dikembangkan untuk menghasilkan media pembelajaran yang menarik dan mudah diakses. Guru Virtual adalah media pembelajaran yang memanfaatkan dan memadukan teknologi TIK dan multimedia dalam proses pembelajaran. Terdapat beberapa alasan mengapa Guru Virtual ini menjadi metode dan media pembelajaran yang tepat untuk diterapkan selama masa pandemi: (1) proses pembelajaran tidak monoton karena dapat didukung oleh animasi yang interaktif; (2) guru dapat terlibat secara aktif dalam menyampaikan materi; (3) mahasiswa atau pembelajar tidak harus mengakses secara realtime, sehingga mahasiswa tidak terbebani oleh permasalahan koneksi internet.

Guru Virtual telah diimplementasikan dalam mata kuliah Analisis Kesalahan Berbahasa pada mahasiswa semester VII Universitas Muhammadiyah Kotabumi. Alasan dipilihnya mata kuliah Analisis Kesalahan Berbahasa adalah: (1) banyaknya konsep yang harus dipahami mahasiswa dalam mata kuliah ini membuat Guru Virtual sangat relevan. Melalui Guru Virtual, mahasiswa dapat mengulang kembali konsep-konsep yang harus dipahami; (2) pemberian contoh melalui studi kasus sangat diperlukan dalam memahami mata kuliah ini sehingga dengan penggunaan Guru Virtual sangat relevan.

\section{Metode}

Metode deskriptif digunakan dalam penelitian ini. (Sugiyono, 2016) mengemukakan bahwa "metode deskriptif melalui pendekatan kualitatif artinya menganalisis bentuk deskripsi tidak berupa angka atau koefisien tentang hubungan antar variabel. Data yang terkumpul berupa kata-kata atau gambar bukan angka". Selanjutnya (Rahmat, 2009) mengemukakan bahwa "pendekatan dalam penelitian kualitatif adalah suatu riset yang bersifat deskriptif dan cenderung menggunakan analisis pendekatan induktif". Teknik pengumpulan data pada penelitian kualitatif termasuk dalam jenis "field research approach".

Penelitian dilakukan sepenuhnya di lapangan. Peneliti akan menjadi instrumen kunci dan harus memahami data dan sumber data kualitatif berupa: narasumber, peristiwa, lokasi, dokumentasi (Sosiologis.com, 2018). Teknik pengumpulan data dilakukan dengan beberapa tahapan seperti: (1) perancangan skenario pembelajaran. Perancangan skenario pembelajaran dilakukan sebelum melakukan proses perekaman. (2) perekaman. Proses perekaman dilakukan 
dengan menggunakan alat seperti: kamera Canon EOS 1300D, tripod Takara ECO-196A, green screen dengan ukuran 3m x 2m, backdrop, backdrop stand, softbox, lighting stand. (3) wawancara daring. Daftar pertanyaan yang diberikan berupa:

\begin{tabular}{c|l}
\hline & \multicolumn{1}{c}{ Pertanyaan } \\
\hline 1 & $\begin{array}{l}\text { Bagaimanakah proses pembelajaran di Universitas } \\
\text { Muhammadiyah Kotabumi setelah terjadi Covid-19? }\end{array}$ \\
2 & $\begin{array}{l}\text { Apakah media Guru Virtual yang digunakan dosen } \\
\text { membantu proses pembelajaran secara daring? }\end{array}$ \\
3 & $\begin{array}{l}\text { Apakah kelebihan media pembelajaran Guru Virtual dalam } \\
\text { pembelajaran daring? } \\
4\end{array}$ \\
& $\begin{array}{l}\text { Apakah kekurangan media pembelajaran Guru Virtual dalam } \\
\text { pembelajaran daring? }\end{array}$ \\
5 & $\begin{array}{l}\text { Bagaimanakah hasil pembelajaran mata kuliah Analisis } \\
\text { Kesalahan Berbahasa dengan media Guru Virtual? }\end{array}$
\end{tabular}

Teknik analisis data yang dilakukan meliputi: (1) Identifikasi hasil wawancara daring antara dosen dan mahasiswa; (2) Mendeskripsikan hasil wawancara daring antara dosen dan mahasiswa; (3) Menghitung skor tes hasil belajar mahasiswa; (4) Mengonversi perhitungan skort es belajar. Berikut ini adalah rumus yang akan digunakan.

$$
\bar{x} \quad \sum_{i-2}^{i} x+\max x+100
$$

\section{Ketcrangan:}

$\bar{x}$ : nilui siswa

$\sum_{i-1}^{k} x i$ : jumlah skor les hasil belajar

$\sum_{i-1}^{k}$ xi moks : jumlah skor mak. Les hasil belajar

ic : jumlah skor tes hasil belajar

Setelah dilakukan perhitungan maka selanjutnya akan dilakukan proses konversi nilai berdasarkan kategori. Berikut adalah tabel kategori kalsifikasi penilaian hasil belajar.

Tabel 1. Klasifikasi l'enilaian Hasil Belajar

\begin{tabular}{|c|c|}
\hline Nilai & Katcgori \\
\hline $\mathrm{P}>\mathrm{ko}$ & Sanpesl bailk \\
\hline $60<\mu=180$ & Busilk \\
\hline $10<\mathrm{p} \leq 60$ & Cakiap \\
\hline $\begin{array}{l}2 \Omega<p=10 \\
P \leqslant 20\end{array}$ & $\begin{array}{l}\text { Kurang } \\
\text { Singal kuran }\end{array}$ \\
\hline
\end{tabular}

(Widoyokn, 2012) 


\section{Hasil dan pembahasan}

\section{Penyusunan materi dan skenario pembelajaran}

Dalam tahapan ini, dosen pelaksana atau pengampu mata kuliah merumuskan materi dan skenario pembelajaran. Proses penyusunan materi disesuaikan dengan RPS yang berlaku di Universitas Muhammadiyah Kotabumi. Prosedur penyusunan materi dan skenario pembelajaran dilakukan secara kolaboratif untuk memperoleh hasil maksimal. Penyusunan materi dan skenario pembelajaran dilakukan sebanyak 6 skenario. Hal ini disesuaikan dengan jumlah video yang akan di produksi. Prosedur perumusan materi: (1) dosen pelaksana/pengampu mata kuliah menyusun materi dan skenario pembelajaran; (2) dosen lainnya melakukan penilaian terhadap rancangan materi dan skenario pembelajaran; (3) dosen pengampu melakukan revisi guna mempertajam materi dan skenario pembelajaran.

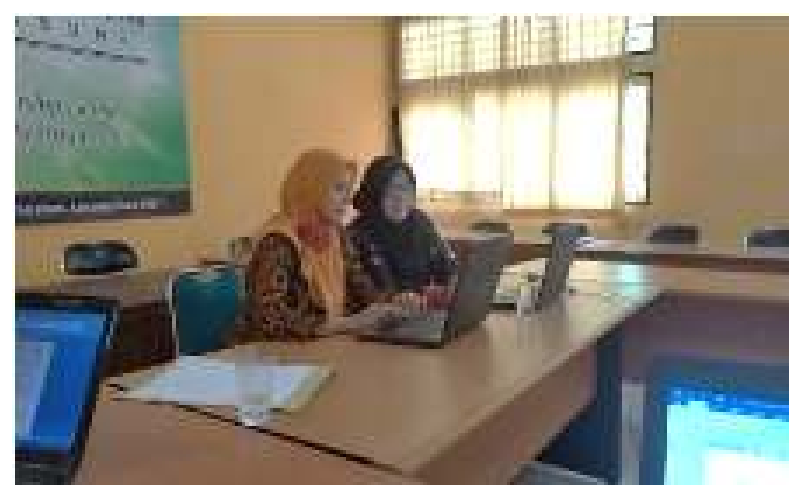

Gambar 1. Perumusan Materi dan Skenario Pembelajaran

\section{Perekaman video pembelajaran}

Perekaman video pembelajaran dilakukan ketika materi dan skenario telah selesai dilakukan. Perekaman video pembelajaran dilakukan sebanyak 6 kali. Berikut ini adalah gambar alat yang digunakan dalam proses perekaman.

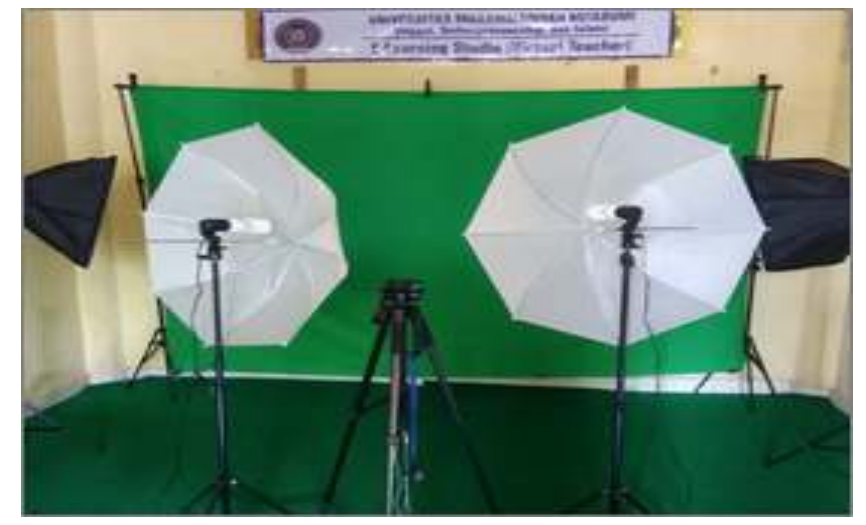

Gambar 2. Peralatan yang digunakan dalam proses perekaman 
Perekaman yang pertama dilakukan pada hari Rabu, 26 Agustus 2020. Proses perekaman dilakukan di studio e-learning Universitas Muhammadiyah Kotabumi. Proses perekaman yang pertama terkait materi (1) pengertian kesalahan berbahasa, (2) pengertian kekeliruan berbahasa, (3) dan perbandingan kesalahan dan kekeliruan berbahasa. Berikut adalah dokumentasi pelaksanaan perekaman video pembelajaran yang pertama.

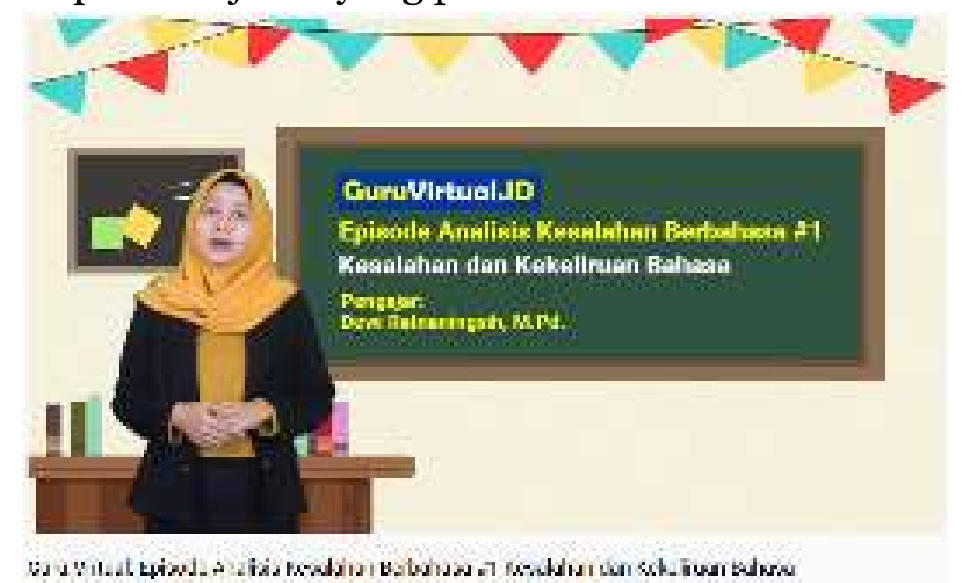

Gambar 3. Proses Perekaman Video Pembelajaran Pertama

Perekaman yang kedua dilakukan di hari yang sama, yakni Rabu 26 Agustus 2020. Proses perekaman dilakukan di dalam studio e-learning Universitas Muhammadiyah Kotabumi. Proses perekaman yang kedua terkait materi klasifikasi kesalahan berbahasa menurut Ahli. Dalam video ini, klasifikasi kesalahan berbahasa yang dipaparkan adalah menurut Tarigan. Berikut adalah dokumentasi pelaksanaan perekaman video pembelajaran yang kedua.

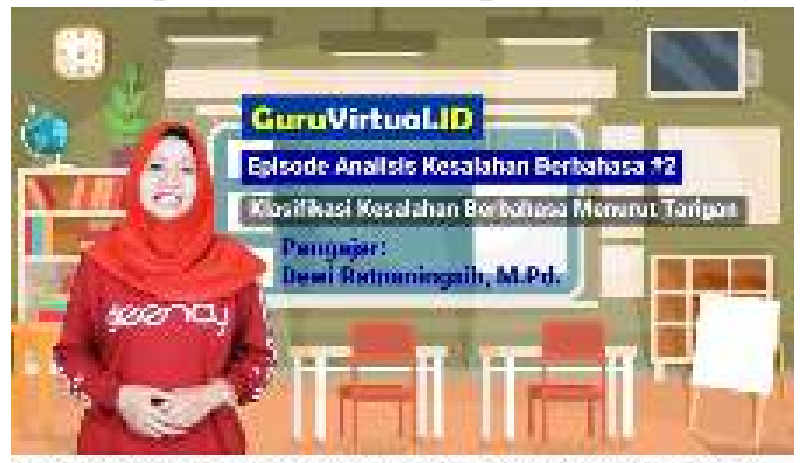

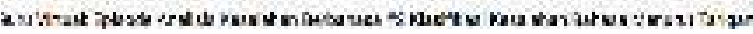

Gambar 4. Proses Perekaman Video Pembelajaran Kedua

Perekaman yang ketiga dilakukan pada hari Selasa, 01 September 2020. Proses perekaman yang ketiga terkait materi (1) klasifikasi kesalahan berbahasa menurut Ahli. Dalam video ini klasifikasi kesalahan berbahasa yang dipaparkan menggunakan teori kesalahan berbahasa Krasen. Berikut dokumentasi pelaksanaan perekaman video pembelajaran ketiga. 


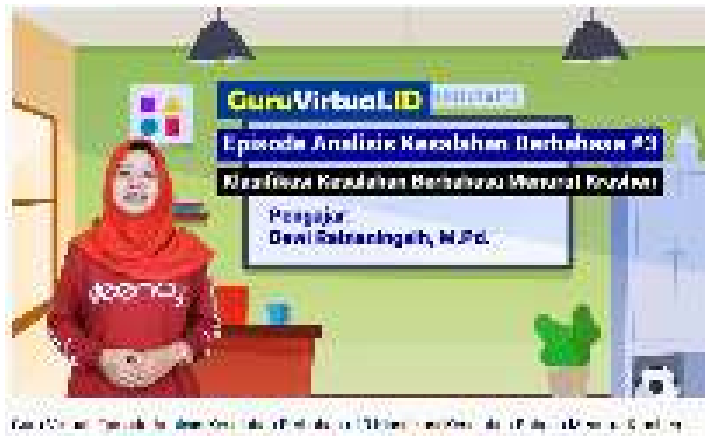

Gambar 5. Proses Perekaman Video Pembelajaran Ketiga

Perekaman yang keempat dilakukan pada hari Selasa, 01 September 2020. Proses perekaman dilakukan di studio e-learning Universitas Muhammadiyah Kotabumi. Proses perekaman yang keempat terkait materi klasifikasi kesalahan berbahasa Tataran Fonologi. Dalam video ini klasifikasi kesalahan berbahasa tataran fonologi terdiri atas: fonem, kluster, diftong, dan pemenggalan kata. Berikut adalah dokumentasi pelaksanaan perekaman video pembelajaran yang keempat.

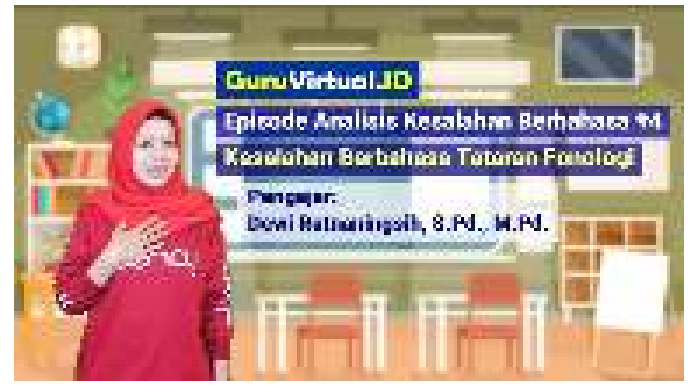

Gambar 6. Proses Perekaman Video Pembelajaran Keempat

Perekaman yang kelima dilakukan pada hari Senin, o7 September 2020. Proses perekaman dilakukan di studio e-learning Universitas Muhammadiyah Kotabumi. Proses perekaman kelima masih terkait materi klasifikasi kesalahan berbahasa Tataran Fonologi. Jika dalam video keempat membahas kesalahan berbahasa bagian fonem, dalam video ini materi yang dibahas mengenai kluster, diftong, dan pemenggalan kata. Berikut adalah dokumentasi pelaksanaan perekaman video pembelajaran yang kelima.

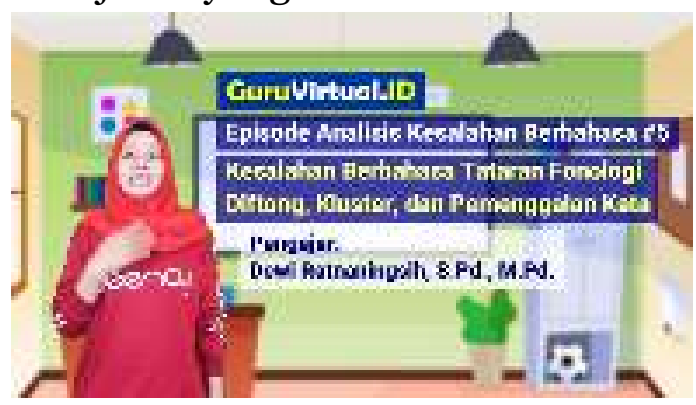

Gambar 7. Proses Perkaman Video Pembelajaran Kelima 
Perekaman yang keenam dilakukan pada hari Senin, o7 September 2020. Proses perekaman dilakukan di studio e-learning Universitas Muhammadiyah Kotabumi. Proses perekaman yang keenam akan membahas materi klasifikasi kesalahan berbahasa Tataran Morfologi. Kesalahan berbahasa Tataran Morfologi yang dibahas meliputi, Berikut dokumentasi pelaksanaan perekaman video pembelajaran kelima.

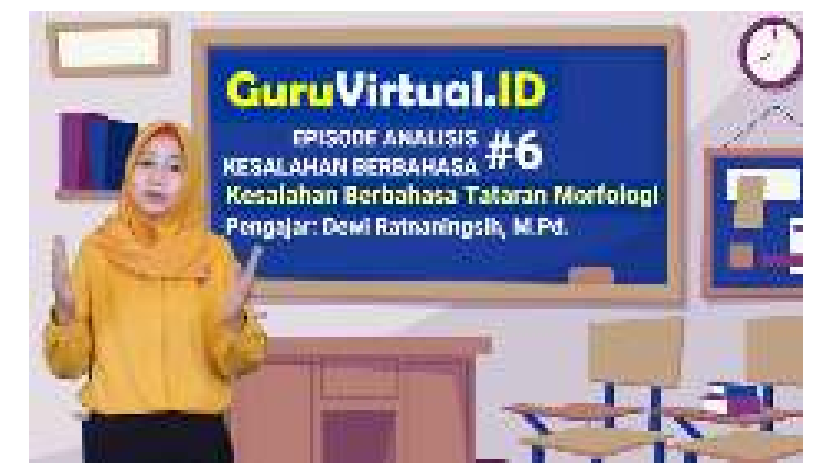

Gambar 8. Proses Perekaman Video Pembelajaran Keenam

\section{Analisis instrumen angket mahasiswa}

Analisis instrumen angket mahasiswa dilakukan melalui virtual, berikut ini adalah daftar pertanyaan yang digunakan untuk menggali informasi terkait pembelajaran selama Covid-19 dan penggunaan Platform Guru Virtual. Berikut ini akan diuraikan hasil jawaban mahasiswa terkait pertanyaan di atas.

1. Bagaimanakah pembelajaran di Universitas Muhammadiyah Kotabumi setelah pandemi?

Pada pertanyaan yang pertama, kebanyakan mahasiswa menyampaikan jawaban yang tidak jauh berbeda, karena hampir semua mahasiswa Universitas Muhammadiyah Kotabumi mendapatkan perlakuan (treatment) yang sama. Kalaupun bervariasi, jawaban tersebut muncul karena tiap dosen juga memiliki cara yang berbeda-beda dalam menyelenggarakan pembelajaran. Pada dasarnya, institusi memberikan otonomi pada dosen masing-masing, untuk menggunakan media yang paling nyaman digunakan. Setelah dilakukan pengkajian terhadap jawaban mahasiswa, berdasarkan jawaban mereka, selama masa pandemi ini dosen Universitas Muhammadiyah Kotabumi menggunakan beragam media pembelajaran, yaitu: (1) Guru Virtual; (2) EdLink; (3) Siakad; (4) Youtube; dan (5) WhatsApp.

2. Apakah media Guru Virtual yang digunakan dosen membantu proses pembelajaran secara daring?

Berdasarkan jawaban mahasiswa pada pertanyaan kedua, Guru Virtual dinilai sangat membantu proses pembelajaran, terutama selama masa Pandemi Covid19. Selain karena media pembelajaran Guru Virtual dikemas sangat menarik, interaktif, dan atraktif, pemanfaatan Guru Virtual dalam proses pembelajaran memiliki banyak kelebihan, yaitu sebagai berikut: (1) memiliki tingkat aksesibilitas tinggi, karena dapat diakses kapan dan dimana saja dengan 
perangkat smartphone; (2) materinya dapat diputar ulang, sehingga mempermudah proses pemahaman materi; dan (3) penjelasan terfokus, tidak buyar, dan terkonsep secara baik oleh dosen.

3. Apakah kelebihan media Guru Virtual dalam pembelajaran daring?

Seperti yang telah disinggung sebelumnya, Guru Virtual memiliki lebih banyak kelebihan dibandingkan media pembelajaran lainnya. Berdasarkan pada jawaban mahasiswa terhadap pertanyaan ini, kebanyakan mahasiswa menjawab bahwa kelebihan Guru Virtual adalah sebagai berikut: (1) mahasiswa mengaku bahwa mereka lebih mudah fokus dan mengikuti materi yang disampaikan melalui Guru Virtual daripada media lain, apalagi yang hanya terbatas pada teks; (2) materi perkuliahan dapat diputar kembali, sehingga mahasiswa dapat lebih mudah memahami materi perkuliahan; (3) mudah diakses, terutama melalui telpon cerdas seperti android; (4) memilki pengajar berpengalaman; (5) Guru Virtual memiliki resolusi gambar yang jernih dan suara yang disampaikan juga terdengar jelas.

4. Apakah kekurangan media Guru Virtual dalam pembelajaran daring? Menurut mahasiswa, kekurangan Guru Virtual adalah karena mahasiswa tidak dapat mengajukan pertanyaan secara langsung, terutama ketika ada materi yang ternyata belum disisipkan dalam konten Guru Virtual. Hal ini terjadi karena pada dasarnya, Guru Virtual adalah media pembelajaran berbasis video, sehingga tidak dapat merespon pertanyaan secara langsung. Oleh karena itu, untuk meminimalisasi kekurangan ini, dosen dapat memanfaatkan kolom komentar, chat, atau melalui grup WhatsApp.

5. Bagaimanakah hasil pembelajaran MK Analisis Kesalahan Berbahasa dengan media Guru Virtual?

Berdasarkan jawaban mahasiswa, penggunaan media Guru Virtual, terutama dalam masa Pandemi Covid-19 ini sangatlah membantu. Melalui media ini, proses pembelajaran berjalan menarik, meskipun tidak dilakukan dalam bentuk tatap muka langsung. Selain itu, media pembelajaran ini masih terbatas penggunaannya, hanya beberapa dosen Universitas Muhammadiyah Kotabumi yang sudah menerapkan media pembelajaran ini secara aktif. Tentunya, mahasiswa dapat lebih termotivasi untuk mengikuti perkuliahan daring. Pelaksanaan perkuliahan daring menggunakan media Guru Virtual telah menyegarkan semangat belajar mahasiswa, apalagi selama pandemi ini masih banyak dosen yang lebih memfokuskan pelaksanaan perkuliahan pada penugasan. Oleh karena itu, menurut penuturan mahasiswa, hasil dari pembelajaran Mata Kuliah Analisis Kesalahan Berbahasa tetap maksimal, meskipun dilaksanakan daring secara penuh. 


\section{Analisis tes hasil belajar mahasiswa}

Tingkat pemahaman mahasiswa terhadap materi dapat diketahui melalui pemberian tes. Analisis hasil tes belajar mahasiswa dilakukan dengan cara mencari rerata nilai dari hasil tes yang diberikan. Berikut ini merupakan tabel perolehan nilai rata-rata hasil tes mahasiswa.

\begin{tabular}{|c|c|c|}
\hline No & Inisial & Nilai \\
\hline 1 & ACAS & 82 \\
\hline 2 & IS & 65 \\
\hline 3 & MSP & 78 \\
\hline 4 & YW & 74 \\
\hline 5 & ES & 70 \\
\hline 6 & WS & 76 \\
\hline 7 & ARA & 75 \\
\hline 8 & ANA & 89 \\
\hline 9 & $\mathrm{ANH}$ & 73 \\
\hline 10 & DAP & 85 \\
\hline 11 & DAD & 74 \\
\hline 12 & $\mathrm{D}$ & 74 \\
\hline 13 & DS & 76 \\
\hline 14 & DGA & 70 \\
\hline 15 & EMS & 75 \\
\hline 16 & EAS & 74 \\
\hline 17 & FFA & 75 \\
\hline 18 & FA & 78 \\
\hline 19 & $\mathrm{HH}$ & 65 \\
\hline 20 & HAS & 82 \\
\hline 21 & IS & 75 \\
\hline 22 & IYA & 74 \\
\hline 23 & $\mathrm{INH}$ & 72 \\
\hline 24 & LP & 73 \\
\hline 25 & MIRAB & 72 \\
\hline 26 & MSP & 71 \\
\hline 27 & MRS & 71 \\
\hline 28 & MIRAB & 71 \\
\hline 29 & NPS & 80 \\
\hline 30 & NPS & 72 \\
\hline 31 & OS & 72 \\
\hline 32 & $\mathrm{RI}$ & 72 \\
\hline 33 & $\mathrm{SF}$ & 95 \\
\hline 34 & $\mathrm{~S}$ & 71 \\
\hline 35 & SAA & 95 \\
\hline 36 & SFM & 71 \\
\hline 37 & WL & 71 \\
\hline 38 & WAA & 80 \\
\hline 39 & YW & 71 \\
\hline 40 & $\mathrm{~A}$ & 72 \\
\hline 41 & OS & 72 \\
\hline 42 & SF & 81 \\
\hline 43 & I & 71 \\
\hline
\end{tabular}




\begin{tabular}{rcr}
\hline No & Inisial & Nilai \\
\hline 44 & NP & 65 \\
45 & INH & 72 \\
46 & M & 74 \\
& Jumlah & $\mathbf{3 4 4 6}$ \\
& Rerata & $\mathbf{7 4 . 9 1 3 0 4 3 5}$ \\
Kategori & Baik
\end{tabular}

\section{Kesimpulan}

Berdasarkan hasil penelitian diperoleh simpulan bahwa Platform Guru Virtual efektif digunakan sebagai media pembelajaran berbasis e-learning. Platform Guru Virtual dikatakan sebagai media pembelajaran yang efektif karena beberapa alasan, seperti: (1) Platform Guru Virtual lebih menarik untuk dilihat jika dibandingkan dengan media pembelajaran yang hanya terbatas pada teks; (2) Melalui Platform Guru Virtual materi perkuliahan dapat diputar berulang kali; (3) Platform Guru Virtual mudah diakses terutama melalui telpon cerdas; (4) Platform Guru Virtual memiliki resolusi gambar yang jernih dan suara yang jelas; (5) Guru Virtual memiliki pengajar yang berpengalaman.

\section{Ucapan Terima Kasih}

Terima kasih diucapkan untuk 1) Majelis Diktilitbang PP-Muhammadiyah yang telah menjadi sponsor penelitian, 2) Universitas Muhammadiyah Kotabumi yang telah memfasilitasi pelaksanaan penelitian, dan 3) Kabag. dan Tim TI Universitas Muhammadiyah Kotabumi yang telah membantu dalam proses pembuatan media pembelajaran daring.

\section{Daftar pustaka}

Adhikari, S. P., Meng, S., Wu, Y. J., Mao, Y. P., Ye, R. X., Wang, Q. Z., Sun, C., Sylvia, S., Rozelle, S., Raat, H., \& Zhou, H. (2020). Epidemiology, causes, clinical manifestation and diagnosis, prevention and control of coronavirus disease (COVID-19) during the early outbreak period: A scoping review. In Infectious Diseases of Poverty. https://doi.org/10.1186/s40249-020o0646-X

Aji, R. (2019). PENGENALAN E-LEARNING. E-learning.

Chandrawati, S. R. (2010). Pemamfaatan el-learning dalam pembelajaran. Cakrawala Kependidikan.

Dahiya, S., Jaggi, S., Chaturvedi, K. K., Bhardwaj, A., Goyal, R. C., \& Varghese, C. (2012). An eLearning System for Agricultural Education. Indian Res. J. Ext. Edu.

Dakwah, S. F., Uin, K., \& Fatah, R. (20 C.E.). SISTEM MANAJEMEN PEMBELAJARAN ONLINE. 60-70.

Fauci, A. S., Lane, H. C., \& Redfield, R. R. (2020). Covid-19 - Navigating the Uncharted. New England Journal of Medicine. 
https://doi.org/10.1056/nejme2002387

Hernawati, K. (2011). E-learning Adaptif Berbasis Karakteristik Peserta Didik. Seminar Nasional Penelitian, Pendidikan Dan Penerapan MIPA.

Hrastinski, S. (2008). Asynchronous \& Synchronous E-learning. EDUCAUSE Quarterly.

Ichwan. (2015). Membuat Metode Pembelajaran dengan Adobe Adobe Flash CS6. Penerbit Andi.

Instruksi Presiden Republik Indonesia nomor 4 tahun 2020 tentang Refocussing Kegiatan, Realokasi anggaran, serta Pengadaan Barang dan Jasa Dalam rangka percepatan penanganan Corona Virus Disease 2019 (Covid-19. (n.d.).

Jayanti, R., \& Rosita, Y. D. (2019). PENGEMBANGAN KOMPETENSI KEBAHASAAN DALAM MENULIS TEKS CERPEN SEJARAH DI MAN 7 JOMBANG. KEMBARA Journal of Scientific Language Literature and Teaching. https://doi.org/10.22219/kembara.vol5.no2.245-253

Kemenkes RI. (2020). Pedoman Pencegahan dan Pengendalian Coronavirus Disease (COVID-19). Germas.

Meilasari, A. W. S. dan P. (2020). Pentigraf sebagai inovasi pembelajaran sejarah pada masyarakat era disrupsi. KEMBARA Journal of Scientific Language Literature and Teaching, 6(2), 131-141.

Purbo, O. W. (2002). Teknologi e-learning Berbasis PHP dan MySQL. Http://Onnocenter.or.Id/Wiki/Index.Php/E-learning.

Rahmat, P. S. (2009). Penelitian Kualitatif. In Journal Equilibrium.

Ratnaningsih, D. (2020). Implementasi Penugasan Dosen di Sekolah (PDS) dalam Mata Kuliah Strategi, Metode, dan Media Pembelajaran Berbasis Lesson Study. Edukasi Lingua Sastra. https://doi.org/10.47637/elsa.v18i1.215

Rusman., Kurniawan, D dan Riyana, C. (2011). Pembelajaran berbasis teknologi informasi dan komunikasi, mengembangkan profesionalitas guru. PT. Raja Grafindo.

Sanaky, H. A. H. (2013). Media Pembelajaran Interaktif-Inovatif. In Kaukaba Dipantara.

Sebayang, R. (2020). Awas! WHO Akhirnya Tetapkan Corona Darurat Global. Www.Cnbcindonesia.Com.

Seok, S. (2008). The aspect of e-learning. International Journal on ELearning, Proquest, 7(4), 725-741.

Sosiologis.com. (2018). Teknik Pengumpulan Data Kualitatif. Sosiologis.Com.

Sugiyono. (2016). Memahami Penelitian Kualitatif. Bandung: Alfabeta.

Windhiyana, E. (2020). DAMPAK COVID-19 TERHADAP KEGIATAN PEMBELAJARAN ONLINE DI PERGURUAN TINGGI KRISTEN DI INDONESIA. Perspektif Ilmu Pendidikan.

https://doi.org/10.21009/pip.341.1 